\title{
Early development of the myxozoan Buddenbrockia plumatellae in the bryozoans Hyalinella punctata and Plumatella fungosa, with comments on taxonomy and systematics of the Myxozoa
}

\author{
Elizabeth U. Canning ${ }^{1}$, Alan Curry ${ }^{2}$ and Beth Okamura ${ }^{3}$ \\ ${ }^{1}$ Department of Biological Sciences, Faculty of Life Sciences, Imperial College London, SW7 2AZ, UK; \\ ${ }^{2}$ Health Protection Agency, Electron Microscopy, Clinical Sciences Building, Manchester Royal Infirmary, Oxford Road, \\ Manchester M13 9WL, UK; \\ ${ }^{3}$ Department of Zoology, Natural History Museum, Cromwell Road, London SW7 5BD, UK
}

Key words: Buddenbrockia, myxoworm, sacculogenesis, muscle primordia, sporogonic cells, cnidarian-like features, Phylactolaemata

\begin{abstract}
We undertook a detailed ultrastructural investigation to gain insight into the early stages of development of the vermiform myxozoan, Buddenbrockia plumatellae Schröder, 1910 in two bryozoan hosts. Early cell complexes arise in the peritoneum after division and migration of isolated cells in the host body wall. The development of cell junctions linking the outer (mural) cells of the complex then produces a sac enclosing a mass of inner cells. Elongation to the vermiform stage (myxoworm) occurs during multiplication and reorganisation of the inner cells as a central core within the single-layered sac wall. The core cells develop into muscle and sporogonic cells separated from the mural cells by a basal lamina. Myogenesis occurs along the length of the myxoworm from cells that differentiate from the central core, and is independent of elongation. Four primary sporogonic cells maintain positions close to the basal lamina, between muscle cells, while giving rise to secondary sporogonic cells that eventually become free in the central cavity. At least some secondary sporogonic cells undergo meiosis. In view of the recent confirmation of the phylogenetic affinity of Buddenbrockia with the Cnidaria, we postulate how features observed in Buddenbrockia may be homologous with cnidarian structures. Finally we propose a new family name, Buddenbrockiidae, to replace Saccosporidae which was proposed previously in breach of the International Code of Zoological Nomenclature.
\end{abstract}

The vermiform parasite Buddenbrockia plumatellae Schröder, 1910 (syn. Tetracapsula bryozoides Canning, Curry et Okamura, 1996), one of a small number of similar endoparasites of bryozoans, has been assigned to the Malacosporea, which is currently recognized as a class within the phylum Myxozoa (Monteiro et al. 2002, Okamura et al. 2002). Relative to the larger class Myxosporea, little is known of the early development, life cycles and species diversity of the malacosporeans, which are at present represented by only three named species. These parasites are of particular interest in view of recent evidence that B. plumatellae, and hence all myxozoans, are members of the phylum Cnidaria (Siddall et al. 1995, Jiménez-Guri et al. 2007a) and group with the Medusozoa (Jiménez-Guri et al. 2007a). This evidence provides a new context in which to interpret myxozoan development. As the vermiform stage of the diploblastic Buddenbrockia is not homologous with triploblastic worms, we propose the name "myxoworm" for it. In this paper we use the term myxoworm for the vermiform stage of Buddenbrockia as described in the present and previous publications.

Only two genera are recognized in the Malacosporea: Tetracapsuloides Canning, Tops, Curry, Wood et Okamura, 2002 with a single species Tetracapsuloides bryosalmonae (Canning, Tops, Curry, Wood et Okamura, 2002) and Buddenbrockia Schröder, 1910 containing
B. plumatellae and Buddenbrockia allmani Canning, Curry, Hill et Okamura, 2007 (see Canning et al. 2007 for review). The first described parasite of this group, recognized as a myxozoan, was the sac-like Tetracapsula bryozoides Canning, Okamura et Curry, 1996, for which the new class Malacosporea was later established (Canning et al. 2000). In spite of having a sac-like rather than worm-like form, this species was subsequently synonymized with $B$. plumatellae by Canning et al. (2002), based on near 18S rDNA sequence identity (Monteiro et al. 2002). Buddenbrockia allmani also develops as sacs. The genus Buddenbrockia thus currently contains species that develop as spore-filled sacs and/or myxoworms. Recent molecular evidence, however, suggests that $B$. plumatellae sacs and myxoworms may represent different species (Tops et al. 2005, Jiménez-Guri et al. 2007a, b).

Several recent studies have focused on the early stages of malacosporean development in bryozoan hosts. Data have been published on presaccular stages and sacculogenesis of T. bryosalmonae in Fredericella sultana (Blumenbach) (McGurk et al. 2006b, Morris and Adams 2006, 2007a). Similar stages have been described for the sac-like B. allmani in the body wall and body cavity of Lophopus crystallinus (Pallas) (Canning et al. 2007) and two studies have addressed some aspects of the early development of worm-like B. plu- 
matellae in the body wall (basal lamina) of Plumatella repens (Linnaeus) (McGurk et al. 2006a, Morris and Adams 2007b). The studies of B. plumatellae dealt with pre-sac cells and sac formation by enclosure of inner cells within a single cell-layered wall and included elongation of sacs to form vermiform stages. However, these studies did not follow in detail the sequences leading to the complex organisation of the highly motile myxoworms. In particular they provided no data on the development of muscle primordia into longitudinal muscle, or on the development and further organisation of different sporogonic cell types before their release into the central cavity. In this paper we describe stages of development of B. plumatellae as seen in Hyalinella punctata Hancock and Plumatella fungosa Pallas, including multiplication of pre-sac cells, their assembly into sacs, and elongation of sacs into myxoworms. We pay particular attention to the four muscle blocks and the role of four sets of pivotal cells that lie between them. We also consider how developmental features may be homologous to those observed in the Cnidaria and address the requirement for a replacement name for the family Saccosporidae, in which the known malacosporeans are currently placed.

\section{MATERIALS AND METHODS}

Colonies of $H$. punctata infected with B. plumatellae were collected from the undersurfaces of lotus leaves and submerged wood in Cowan Lake $\left(39^{\circ} 23^{\prime} \mathrm{N}, 38^{\circ} 54^{\prime} \mathrm{W}\right)$, Clinton County, Ohio, USA on $16 / 07 / 04$. The single colony of $P$. fungosa with a cryptic infection of $B$. plumatellae was obtained from the Kennett and Avon Canal $\left(51^{\circ} 24^{\prime} \mathrm{N}, 01^{\circ} 08^{\prime} \mathrm{W}\right)$ at Padworth, Berkshire, UK. The overt $B$. plumatellae infection in $P$. fungosa was expressed in a laboratory culture system established from the bryozoan colony as described in Canning et al. (2002).

For electron microscopic investigation infected bryozoan colonies were fixed in $2.5 \%(\mathrm{v} / \mathrm{v})$ glutaraldehyde in $0.1 \mathrm{M}$ cacodylate buffer, $\mathrm{pH} 7.4$, and postfixed in $1 \%(\mathrm{w} / \mathrm{v})$ osmium tetroxide. The specimens were dehydrated in a graded series of alcohol and embedded into Araldite resin (TAAB Laboratories). After polymerisation, the resultant resin blocks were sec- tioned using a Reichert Ultracut ultramicrotome. Sections were mounted onto copper mesh grids and stained with uranyl acetate and lead citrate, before examination with a Philips CM10 transmission electron microscope and image capture. Unfortunately grit, adherent to the surface of the bryozoans, caused score marks on some of the sections.

A specimen orientated for transverse sectioning of myxoworms was carefully cut from its original resin block using a razor saw and re-orientated so that longitudinal sections were possible from this specimen. The re-orientated piece of resin block was attached to a pre-polymerized resin block using liquid Araldite resin that was hardened in a $60^{\circ} \mathrm{C}$ oven overnight. After polymerisation and careful trimming, the re-orientated block was again sectioned on a Reichert Ultracut ultramicrotome and the resultant sections stained before examination, as outlined above.

\section{RESULTS}

\section{Pre-sac stages}

Isolated rounded or oval cells and small groups of closely associated cells were found beneath the epithelium within the basal lamina (Figs. 1, 2). The nuclei had a large nucleolus and the membranes of the nuclear envelope were quite widely spaced between pores, the inter-membrane space being occupied by amorphous material similar to material in the extensive endoplasmic reticulum (ER) (Fig. 3). Prominent features were typical malacosporean sporoplasmosomes, $300 \mathrm{~nm}$ in diameter and membrane-bound and either distributed throughout the cytoplasm or peripherally located. There were also large vesicles, bounded by a fine membrane, many of which were partially surrounded by a cisterna of rough $\mathrm{ER}$, with the ribosomes adjacent to the vesicle membrane prominently outlining the vesicle (Fig. 4). The contents of these vesicles appeared floccular, rather than homogeneous. Some cells in the groups contained small angular vacuoles with homogeneous contents that were not present in other cells of the group, suggesting a possible differentiation of function at an early stage. Mitochondria with tubular cristae, and lipid globules were common.

Figs. 1-7. Buddenbrockia plumatellae in Plumatella fungosa (Figs. 1-5) and Hyalinella punctata (Figs. 6, 7). Fig. 1. Isolated cells in the basal lamina (BL) close to disrupted peritoneal tissue (PT), at the edge of the body cavity with cilia (C). Most cells contain dense sporoplasmosomes and one of the cells shows the characteristic malacosporean nucleus (N) with large nucleolus. Arrow points to a vacuole with floccular contents, which is enlarged in Fig. 4. Fig. 2. Closely grouped cells, not united by cell junctions, in the host's basal lamina (BL), between the epithelium (E) and peritoneum (PT). The small lucent vacuoles in one cell (arrow) resemble those in Type A cells (Fig. 13). Part of the nuclear envelope of this cell is enlarged in Fig. 3. M - mural cells of an adjacent myxoworm in the body cavity (BC). Fig. 3. Part of the nuclear envelope enlarged from Fig. 2, showing amorphous material in the inter-membrane space and in endoplasmic reticulum (ER). N - nucleus. Fig. 4. Enlargement of part of Fig. 1, showing vacuole with floccular contents and fine membrane (arrowhead), outlined by rough endoplasmic reticulum. Fig. 5. Sacculogenesis in a space in the peritoneum. Mural cells (M) united by simple cell junctions (arrowheads) surround free inner (sporogonic) cells (S). Two cells (arrows) are being squeezed between mural cells as the sac closes. Fig. 6. Sacculogenesis. Mural cells (M), now with junctions involving tight and gap regions (arrowheads), enclosing an inner binucleate cell (N). Peripheral sporoplasmosomes are abundant in mural cells only. The boxed area is enlarged in Fig. 7. Fig. 7. Cell junction enlarged from Fig. 6 . Scale bars: Fig. $1=2.8 \mu$ m; Fig. $2=3.0 \mu$ m; Fig. $3=600$ nm; Fig. $4=350$ nm; Fig. $5=3.2$ m; Fig. $6=3.0 \mu$ m; Fig. $7=$ $1.35 \mu \mathrm{m}$. 
Canning et al.: Early development of Buddenbrockia

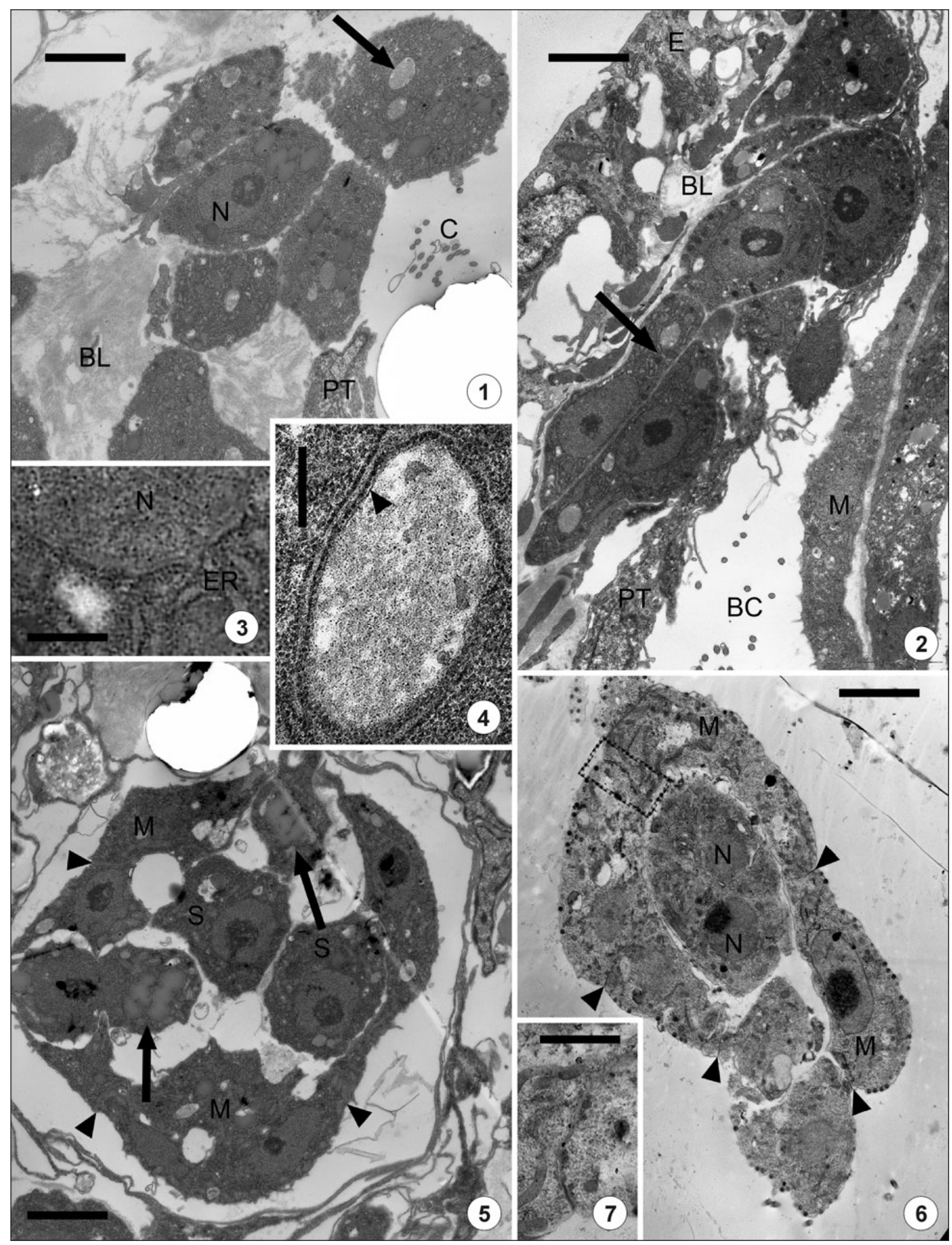




\section{Sac formation}

Initially, when the cells were associated as small groups, there were no cell junctions uniting the individual cells even when closely apposed. At a later stage, when the parasites had migrated and were associated with the peritoneum, and later still when they had crossed into the coelomic cavity, the cells gained a more permanent association by forming a sac with an external layer of mural cells, linked by true cell junctions, surrounding a loose collection of inner cells. Before the outer layer was complete, some cells appeared to be squeezed between pseudopodial extensions, as if the squeezed cells were being included or excluded from the sac wall or inner mass (Figs. 5, 6). Division of inner cells was indicated by the presence of two nuclei in one of the cells (Fig. 6). In further development the junctions of mural cells resolved into junctional complexes, with an external tight region and an inner gap region that often followed a tortuous path towards the inner boundary (Fig. 7). Such junctions have been seen previously in mural cells of more mature stages of $T$. bryosalmonae (Canning et al. 2000), B. plumatellae (Canning et al. 2002) and B. allmani (Canning et al. 2007). These mural cells, in increasing numbers, formed the cellular wall that surrounded the inner cells throughout their differentiation and development (Figs. 8-12). Mural and inner cells both contained vacuoles, not surrounded by ER, with clumped contents and there was an occasional collection of refractile globules that clustered between the cells in the cavity (Fig. 8). Similar refractile clusters were found in sections of the enlarging myxoworms (Figs. 10, 12) and possibly represented excretory products that ultimately merged into a single clump (Fig. 16). In the earliest stages, sporoplasmosomes were abundant in mural cells (Fig. 8), confined to a peripheral ectoplasmic layer from which ribosomes and other cell organelles were absent. At one pole the sporoplasmosomes showed a lucent elliptical region with a dense core. This pole was directed towards the surface (Fig. 9). At this stage the surface of the sac was smooth, with only a few minor projections from some cells.

\section{Myxoworm formation}

At first, the inner cells as seen in transverse section (TS), were organized as a small bundle separated from the wall by an irregular space containing fibrous material and some small particles (Fig. 8) that represented the forerunner of the basal lamina, which would form a link between inner and outer cells. The sacs appeared circular or oval in cross-section but, even at this stage, their true shape is likely to have been vermiform, as corresponding longitudinal sections (LS) showed a similar arrangement of cells. In the presumed youngest myxoworm observed in LS, the mural cells surrounded a core of undifferentiated cells that twisted around each other as in a "rope", separated from the mural cells only by the basal lamina precursor (Fig. 10). There were no tight junctions between core cells. This stage demonstrates that elongation into a myxoworm and central cavity formation are not dependent on the presence of longitudinal muscles, as elongation preceded the differentiation of muscle cell precursors.

\section{Muscle and sporogonic cell differentiation}

Enlargement of the sac diameter and increase in the number of mural and inner cells was accompanied by differentiation of the inner cells into muscle primordia and sporogonic cells and by gradual depletion of sporoplasmosomes from the mural cells (Fig. 11). In TS the mural cells were generally convex externally, with numerous small projections from the ectoplasmic layer that harboured the remaining sporoplasmosomes, and were flattened internally. Nuclei showed a prominent nucleolus or sometimes two (Fig. 12), suggestive of the onset of intranuclear division. In some examples, the separate nucleoli lay at opposing poles in an arrangement typical of cryptomitosis (Fig. 13), as described previously for myxozoans (Marquès 1986-1987).

As in the mural cells, division of both types of inner cell was indicated by the presence of two nucleoli in many cells and occasionally by two separate nuclei (Fig. 12). Lining the wall, but still separated from it by the basal lamina, lay four ovoid cell groups, each comprised of 3 to 8 cells as seen in TS, and positioned tetra-

Figs. 8-12. Buddenbrockia plumatellae in Hyalinella punctata. Fig. 8. Sacculogenesis: the wall of mural cells (M) with sporoplasmosomes is now complete around a core of inner cells linked by gap junctions. As well as presumed excretory vesicles (EX), a cluster of refractile globules $(\mathrm{G})$ lies in the narrow cavity between mural and inner cells. Fig. 9. Enlargement of boxed area of Fig. 8 showing sporoplasmosomes in ectoplasmic layer of mural cells, with the elliptical region containing a dense bar aligned parallel to the surface. Fig. 10. Longitudinal section of a stage corresponding to Fig. 8, close to the host's peritoneum (P). The point at which the myxoworm with a smooth outline emerges from the peritoneum may be at bottom left. The inner cells are seen as a rope-like core fitting closely to the sporoplasmosome-containing mural cells (M). A cluster of extracellular globules (G) resembles those in Fig. 8. Fig. 11. Transverse section of a myxoworm shortly after reorganisation of the central core. Within the mural cells (M), now with fewer sporoplasmosomes, are four primary Type A cells (A) and their secondary derivatives (arrows) linking the primaries and separating the four bundles of undifferentiated primordial muscle cells (MP) from the central cavity. Fig. 12. Part of an enlarging myxoworm, with several cells in division, as indicated by two nucleoli in some nuclei (single arrows). The secondary Type A (A*) and denser B (B) cells now almost fill the central cavity and the muscle cells exhibit pale processes (double arrows) directed towards the basal lamina (BL) between mural cells (M) and inner cells. One muscle cell is binucleate $(\mathrm{N}) . \mathrm{G}$ - secretory globules. Scale bars: Fig. $8=1.8 \mu \mathrm{m}$; Fig. $9=350 \mathrm{~nm}$; Fig. $10=4.0 \mu \mathrm{m}$; Fig. $11=4.5 \mu \mathrm{m}$; Fig. $12=$ $4.0 \mu \mathrm{m}$. 

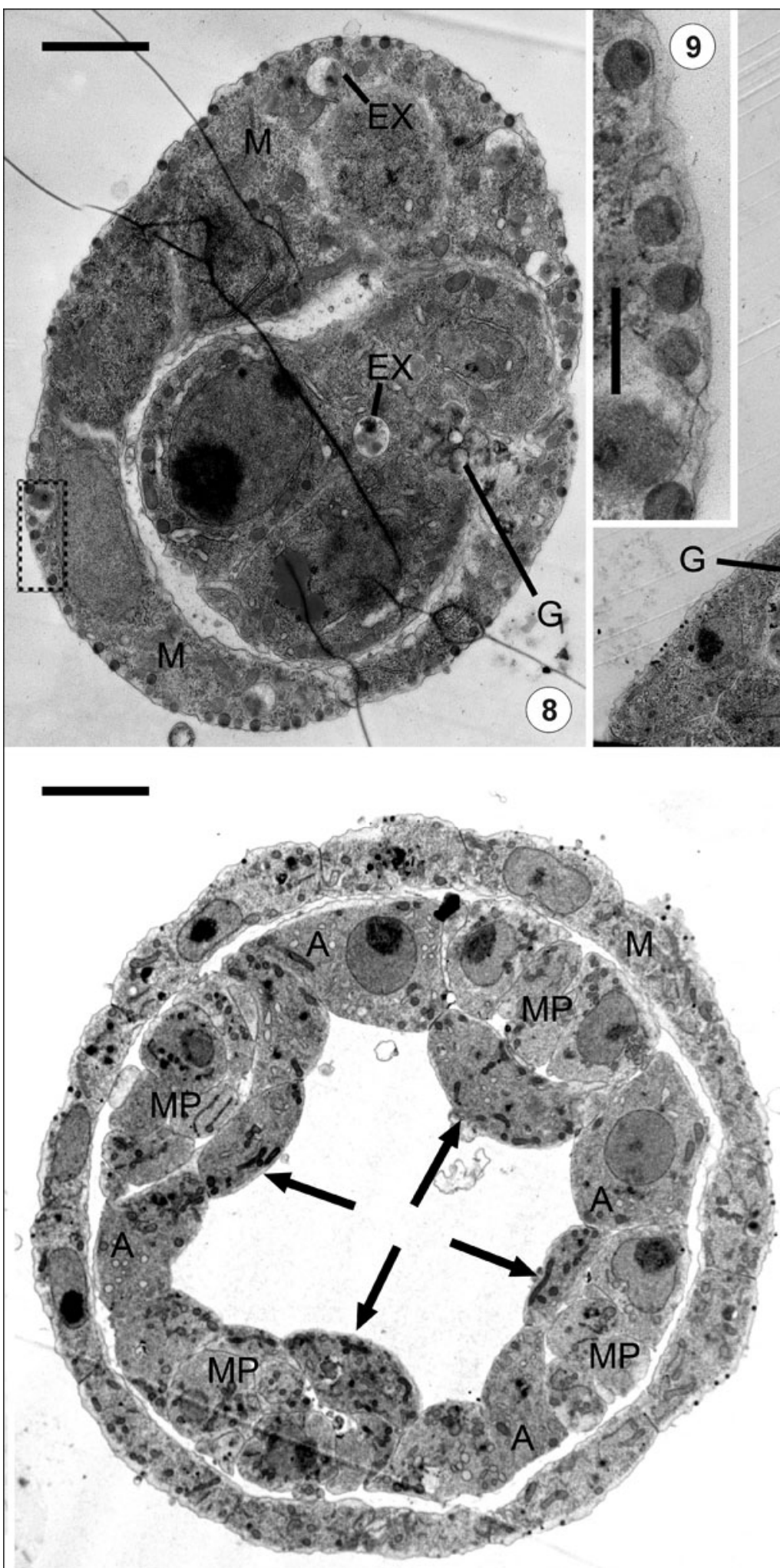
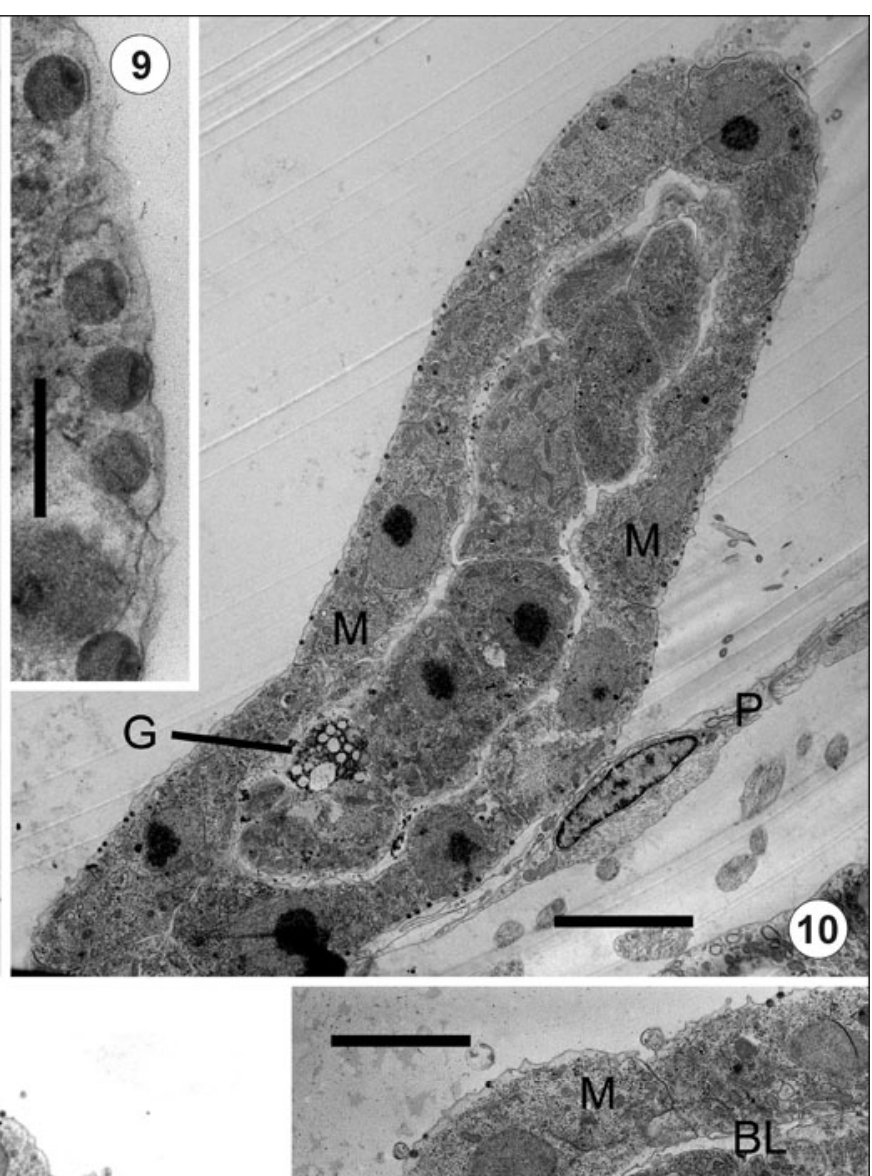

(11)

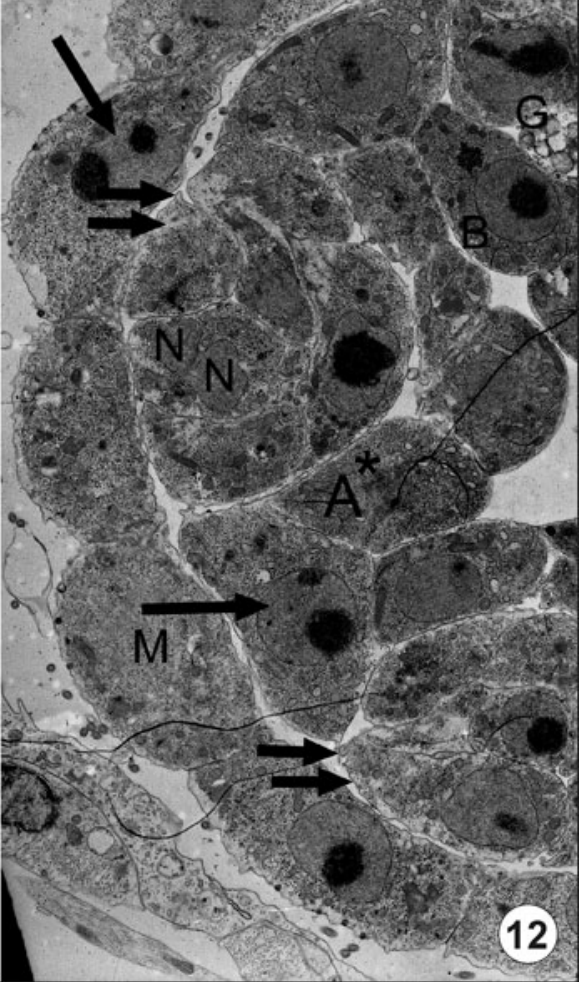


radially (Fig. 11). These cells were primordial muscle cells that were closely apposed with simple cell junctions. Between each of the four primordial muscle cell groups lay a single large cell abutting the muscle primordia and completing the inner cell ring within the cell wall (Figs. 11, 12). This left a small central space, which at first increased then gradually decreased as the number of inner cells increased. The four cells abutting the wall, previously named primary Type A cells (Canning et al. 2002), maintained their positions throughout development. The secondary products of these cells are precursors of spores. Thus, cells of this sequence, both primary and secondary, are sporogonic cells.

In the youngest myxoworms observed the muscle cells showed little cytoplasmic differentiation (Fig. 11). As the number of cells increased, each muscle group became roughly triangular and the cells showed a dense region containing the nucleus and abundant mitochondria, and a pale region, largely depleted of these organelles, that was projected towards the mural cells (Fig. 13). The cells on the inner side of the group directed their projections around or between the more outwardly situated cells. The cytoplasm of the projections contained a network of very fine muscle fibres, a few ribosomes and little else.

The primary sporogonic (Type A) cells, characterised by the presence of small lucent vacuoles, gave rise to secondary sporogonic cells that curved around the inner borders of the muscle groups as a single layer and connected the four primary cells. The secondary cells, initially only one or two between primaries (Fig. 11), were later seen as two interspersed types (Figs. 12, 13). These were the secondary Type A cells harbouring small lucent vacuoles as in the primaries, and denser cells lacking the vacuoles, that had been named Type $\mathrm{B}$ cells (Canning et al. 2002). At this stage, the sporogonic cells were connected by junctional complexes comprised of tight and gap regions, with the tight region on the inner side, in contrast to the junctions between mural cells. Both types of sporogonic cell became more numerous with the growth of the worm, initially maintaining the arrangement as a single layer but gradually multiplying inwards and filling most of the internal space (Figs. 13, 16).

\section{Cell interactions in transverse and longitudinal sections}

The vermiform organisation could be deduced from the arrangement of cells that had been seen in TS, i.e. within the bounding wall of mural cells a single longitudinal column of primary sporogonic Type A cells lies between each longitudinally-running muscle block. The muscle blocks are separated from the internal cavity by one or more columns of secondary sporogonic cells (Types A and B). In longitudinal views of the same or similar parasites, most sections cut through the columns of muscle primordia and underlying secondary sporogonic cells, rather than through any of the columns of primary Type A cells. Although it proved impossible to identify with certainty the same myxoworms in the TS and LS, the progress of development in the different views, through young, middle and older specimens, could be related by the diameters of the sections, the abundance of inner cells and by the relative abundance or paucity of sporoplasmosomes in the mural cells. Specimens such as Fig. 10, which appeared to show the tip of the myxoworm, could be misleading, as the tight junctions at the closed end suggest that the specimen had been cut obliquely through the superficial part of several cells. Thus the ends of the myxoworm and the relationship of the base to the peritoneum were not identified.

In young myxoworms, the longitudinal views confirmed that the muscle primordial cells were not connected by tight junctions (Figs. 14, 15). The outer projections of sequential muscle cells overlapped, interdigitated and were directed towards one end of the organism (Fig. 14). The fibres in the projections, which had appeared as a network in transverse orientation, were now seen arranged longitudinally, except where projections of cells on the inner side of the bundle were oblique as they curved round the outer cells. The muscle fibres were non-striated, and at this stage were confined to the external regions of the cells. Inner differentiation of myofibrils was only seen in the present study in one myxoworm sectioned transversely (Fig. 16) but had been seen in more mature 'worms' in $H$. punctata in a previous study (Okamura et al. 2002). The central cytoplasm of the muscle cells harboured the nucleus and

Figs. 13-17. Buddenbrockia plumatellae in Hyalinella punctata. Fig. 13. Part of a transverse section showing clearly the primary Type A (A) and secondary (A*) cells with lucent vacuoles differing from the denser B cells (B). The regions of the muscle cells that develop muscle fibres are the outwardly-directed processes (double arrows) containing little more than ribosomes. Single arrow points to a nucleus with nucleoli at opposite poles within the nuclear envelope. Fig. 14. Longitudinal section showing muscle cells (MC) internal to the mural cells (M) and basal lamina (BL). The muscle cells interdigitate and point in one direction. Their outer borders contain smooth muscle fibres. Fig. 15. The outer regions of muscle cells seen in longitudinal section, showing longitudinally-arranged muscle fibres. Fig. 16. Transverse section of an unusually well-developed muscle bundle in a young myxoworm, showing muscle fibres in their inner borders $\left(\mathrm{F}^{1}\right)$ as well as in the processes $\left(\mathrm{F}^{2}\right)$ adjacent to the basal lamina (BL). Primary Type A (A) and Type B (B) sporogonic cells still separate the muscle cells from the central area, now with the cavity filled with $B$ cells, there being few secondary Type A cell $\left(A^{*}\right)$ remaining. There is a central accumulation of excretory products (EX). Fig. 17. Muscle cell undergoing endogeny at a time when its outer cytoplasmic projections (arrow) are not fully developed. $\mathrm{E}-$ endogenous cell; $\mathrm{N}$ - nuclei. Scale bars: Fig. $13=3.3 \mu \mathrm{m}$; Fig. $14=1.6 \mu \mathrm{m}$; Fig. $15=1.0 \mu \mathrm{m}$; Fig. $16=5.0 \mu \mathrm{m}$; Fig. $17=$ $1.5 \mu \mathrm{m}$. 


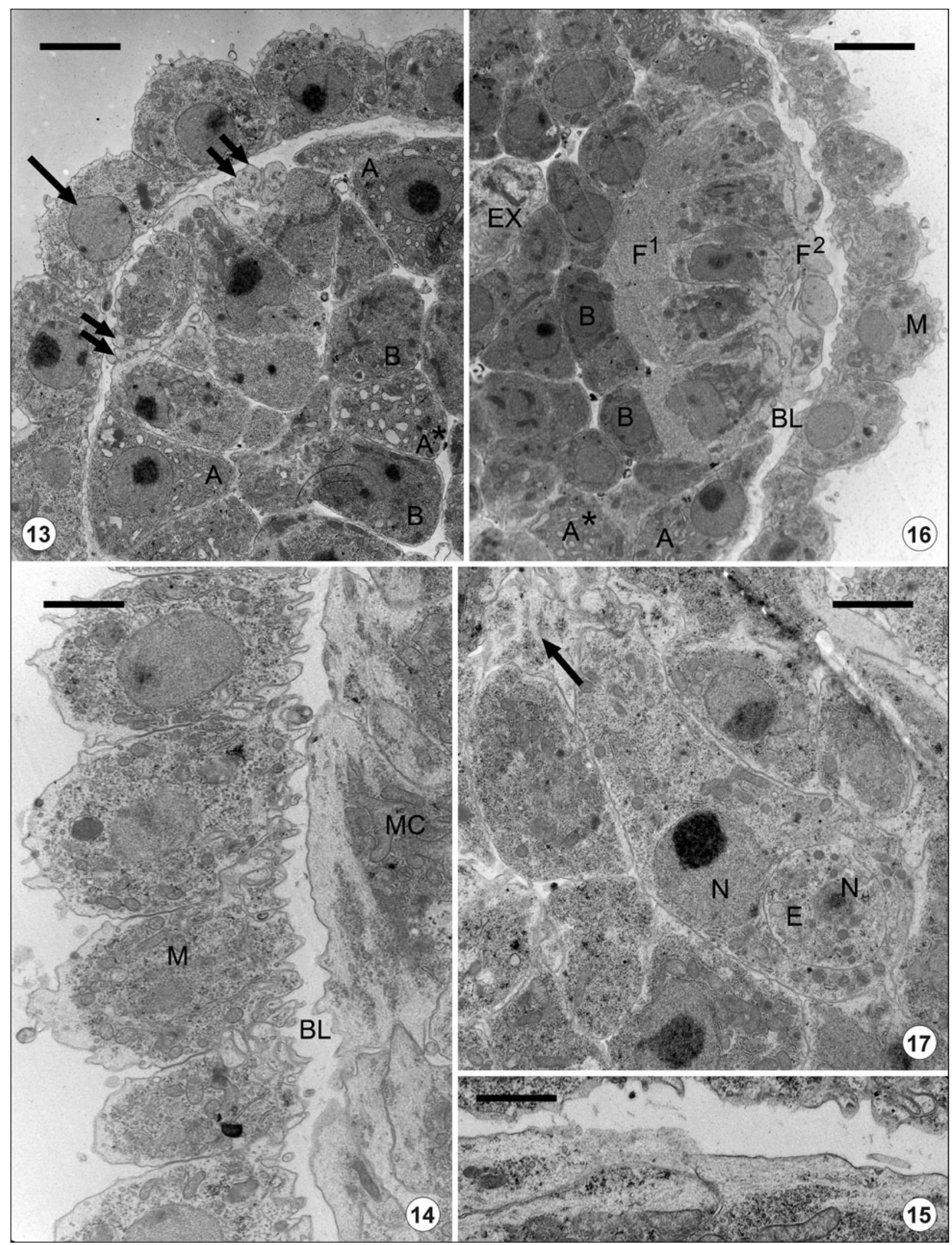


was packed with mitochondria and ribosomes. In one case an endogenous cell was seen (Fig. 17).

In the rare longitudinal sections showing primary sporogonic (Type A) cells in a single column, these cells were seen flanked by parts of the muscle primordia and some secondary sporogonic cells (Fig. 18). The tight junctional region of the cell junctions were seen between the primary and secondary sporogonic cells (Fig. 18) but rarely between successive primary cells in the longitudinal row. This can be explained, as sections passing through the fibrous, outer borders of the muscle cells, would not necessarily pass through the tight junctions that are located on the inside of the primary Type A cells. Although parts of inner cells, not bound by tight junctions, seemed to be detached, this was probably artifactual due to fixation and embedding procedures and, in life, the cells would have formed a complete layer internal to the muscles, before their liberation to form spores.

Repeated multiplication of sporogonic cells led to the cavity of the sac being packed with cells, filling all the space not occupied by the muscle blocks. In one tangential view, there was a group of primary and secondary Type A cells that were attached by tight junctions in a polygonal arrangement (Fig. 19). It is of interest that the arrangement of primary and secondary cells, closely attached by junctions, with the tight region on the inner border, isolated the muscle bundles and mural cells from the central cavity, where spore development is normally completed. The primary sporogonic (Type A) cells were isolated from the mural cells by the basal lamina but the striated tubules crossing the basal lamina and linking the primary sporogonic cells to the mural cells that had been so prominent in the older myxoworms of $B$. plumatellae in $H$. punctata (Canning et al. 2002, Okamura et al. 2002) were not seen in the present smaller myxoworms, nor were any polar capsules seen in the mural cells that, in the previous study in $H$. punc$t a t a$, had been the clue to the myxozoan nature of the vermiform parasite. Further examination of the 2002 material confirmed the strongly fibrous nature of the basal lamina and the myofibril packed inner and outer borders of the muscle cells (Figs. 20, 21).

\section{Release of sporogonic cells}

Later stages were not seen in the new material from $H$. punctata and completion of sporogony has so far not been observed in this host. Division of mural cells in the parasites infecting $P$. fungosa allowed enlargement of the myxoworms and increase in the volume of the cavity. The primary Type A cells became separated from secondary cells but remained in touch with the basal lamina and were linked to the muscle blocks by very thin margins (Figs. 22-24). As a result of the release of the secondary Type A and B cells, the primary sporogonic (Type A) cells and their connections with muscle remained as the barrier between the cavity and the basal lamina, while the mural cells and basal lamina formed barriers to the bryozoan coelom.

Very few, if any, secondary Type A cells persisted among the large clumps of Type B cells liberated into the central cavity (Figs. 22, 23). Many of the B cells contained one or more vacuoles, some as large as the cell nucleus, full of lucent globules against a dark background (Fig. 24). Among the true cells were numerous, apparently anucleate, cytoplasmic spheres ranging from $1.0 \mu \mathrm{m}$ to $3.0 \mu \mathrm{m}$ in diameter (Figs. 22, 23). Many of these contained the same kind of vacuolar material as formed in the B cells and may have been budded from them as a means of eliminating waste products. The nuclei of some of the $\mathrm{B}$ cells had entered into meiosis, showing persistent nucleoli at least in leptotene, and formation of synaptonemal complexes (Fig. 25). Further stages in spore maturation were not present.

\section{DISCUSSION}

\section{Development}

Buddenbrockia plumatellae was described by Schröder (1910) using light microscopy to study live myxoworms and stained sections. Although interpretations of the roles of some stages were incorrect, e.g. that the spores were embryos, Schröder's description and illustrations were remarkably accurate, even to recognition of different types of inner cells and to four cell blocks as muscle in maturing and mature myxoworms. It is of interest that we have never found spores in myxoworms parasitizing Hyalinella punctata and many of the free sporogonic stages that we had examined (Canning et al. 2002) appeared degenerate, suggesting that B. plumatellae cannot complete its life cycle in this host. It is also unusual that polar capsules were present in mural cells of myxoworms in $H$. punctata (Canning et al. 2002, Okamura et al. 2002) but have not been reported in this site in other hosts.

Figs. 18-21. Buddenbrockia plumatellae in Hyalinella punctata. Fig. 18. Longitudinal section showing a row of primary Type A sporogonic cells (A) flanked by muscle cells (MC) within the mural cells (M) and basal lamina (BL). Tight junctions are not visible between the primary sporogonic cells as the section does not pass through the internal parts of these cells but a tight junction between a primary and a secondary (SC) sporogonic cell is visible (arrow). Fig. 19. Longitudinal section passing through a polygonal arrangement of primary (A) and secondary $\left(\mathrm{A}^{*}\right)$ Type A sporogonic cells, showing tight junctions between them (arrowheads). M - mural cells; BL - basal lamina. Fig. 20. Oblique section of a mature myxoworm, passing through the outer part of muscle cells (MC), packed with smooth fibres and joined by gap junctions, the strongly fibrous basal lamina (BL) and mural cells (M). Fig. 21. Longitudinal section, passing through mature muscle (MC) with fibrous regions on both sides of the cells, free B cells (B) in the body cavity, the basal lamina (BL), and mural cells (M). Scale bars: Fig. $18=3.0 \mu \mathrm{m}$; Fig. $19=1.5 \mu \mathrm{m}$; Fig. 20 $=360 \mathrm{~nm}$; Fig. $21=2.25 \mu \mathrm{m}$. 


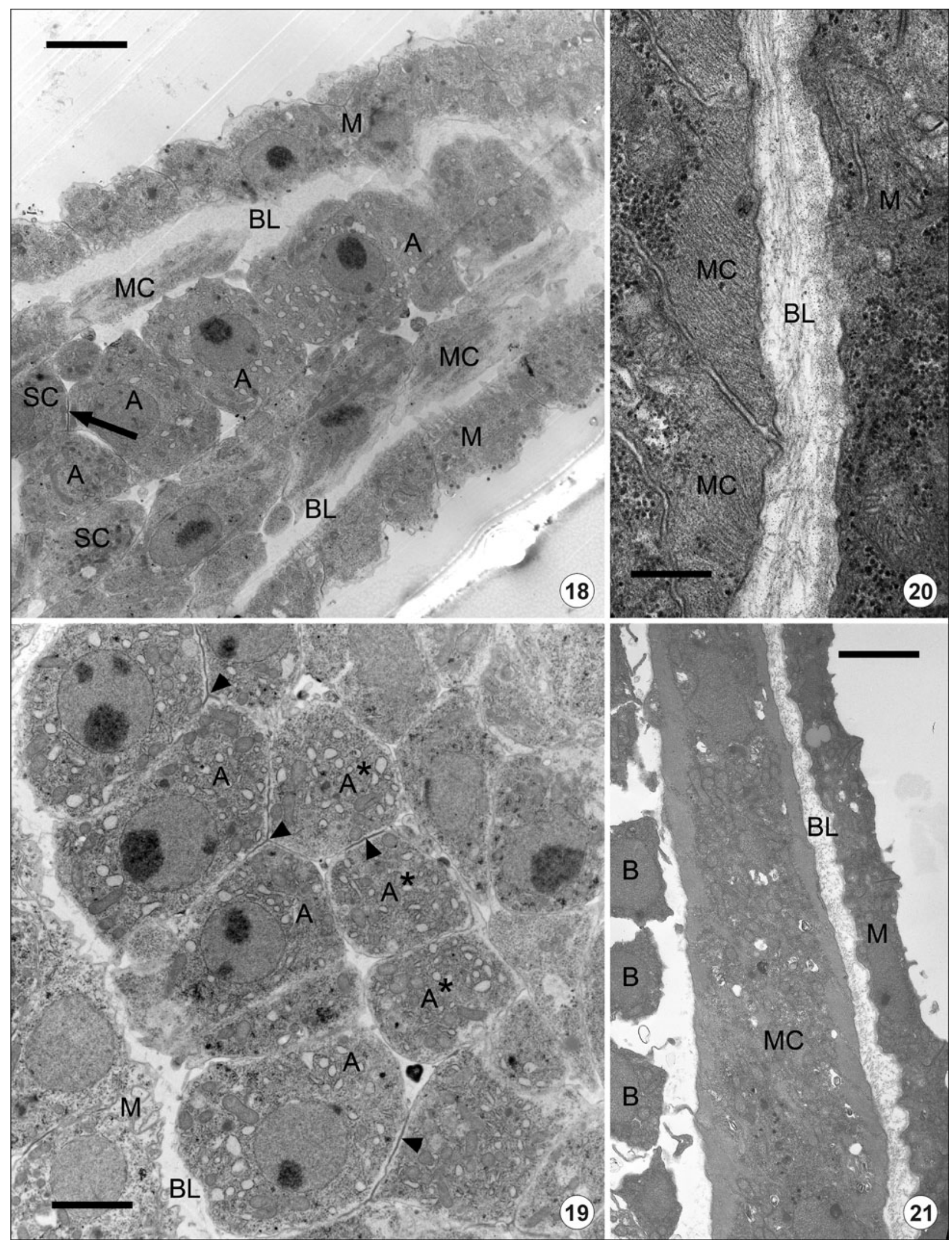


Until recently, there was almost no information about development of malacosporeans in bryozoans prior to their organisation as sacs or vermiform stages. The only observation, in the first descriptions of the three species, was of isolated cells of $B$. plumatellae in the body wall of Plumatella fungosa. These contained numerous dense bodies thought at the time to be lipid (Canning et al. 2002) but are herein recognized as sporoplasmosomes as observed in corresponding stages in Buddenbrockia allmani (Canning et al. 2007) and T. bryosalmonae (Morris and Adams 2006). In a recent series of papers discussed below, presaccular stages of Tetracapsuloides bryosalmonae, $B$. plumatellae and B. allmani have been described at light microscopic and electron microscopic levels. The parasites were studied in different bryozoan hosts and some differences in the observations may be due to interpretation or to different fixation and embedding techniques.

McGurk et al. (2006b) made light microscopic observations on $T$. bryosalmonae sacs in Fredericella sultana that had been established in culture from wild populations. Live parasites were observed over a period of five days, changing from particles swirling in the metacoel, through spheroid stages attached to the inner surface (presumably) of the peritoneum, and finally to free sacs into the metacoel. Morris and Adams (2006) also studied $T$. bryosalmonae in F. sultana, using immunohistochemistry, confocal microscopy, scanning electron microscopy and transmission electron microscopy (TEM). All methods showed proliferating presaccular stages with individual cells attached by filopodia, mainly to the peritoneum. TEM revealed peripheral sporoplasmosomes in these cells, with the characteristic bar-like structure orientated parallel to the surface. Morris and Adams (2007a) extended these studies into sacculogenesis, describing that the isolated presaccular parasites formed aggregates that resolved into sacs, with mural cells surrounding presporogonic cells. It was proposed that mural cells were added to the wall of the sac by attachment and assimilation of free cells from the proliferating presaccular pool but they did not report this for B. plumatellae (Morris and Adams 2007b). We found no evidence for growth of the sac wall by cell assimilation in our study of B. plumatellae. In contrast, divisions of the nucleolus and polar positioning of the nucleolar products were common indicators of intranuclear division. These are characteristic of cryptomitosis that has previously been described for Myxozoa (Marquès 1986-1987) and provide ample evidence of cell division to account for sac wall enlargement. We suggest that assimilation of cells into the sac wall during early stages of sac development would seem unlikely since presaccular pools could be derived from multiple infections resulting in the production of genetic chimeras. Also, presaccular cells of B. plumatellae develop in the body wall and no free cells circulating in the body cavity have been reported for this species (see below).

Morris and Adams (2007b) made observations on B. plumatellae in Plumatella repens that showed similar stages to those of $T$. bryosalmonae, except that presaccular stages, rather than being free in the coelom or attached to the peritoneum, were sited predominantly in the basal lamina of the body wall, later migrating to lie just within the peritoneal boundary with the coelom. Only in this position was sacculogenesis initiated, by formation of a layer of cells, attached to one another by myxozoan type junctions, surrounding a "pseudosyncytium". The whole structure was encapsulated by a "pseudocapsule" that they interpreted to be comprised of degenerating host tissue. Also in their interpretation, the "pseudosyncytium" would act as the base for elongation of the myxoworm into the coelom. They reported direct attachment of host collagen to the surface of presaccular parasites in the basal lamina and, in one example, that parasite collagen arising within a "pseudosyncytium" penetrated an encapsulating host cell forming the anchorage of the syncytial base of the myxoworm to the peritoneum.

Our observations of B. allmani in Lophopus crystallinus (Canning et al. 2007) and of B. plumatellae in the present study are in agreement on the sites of development. However, no collagenous associations between host and parasites were found. If host collagenous attachments are formed in the basal lamina, they must be transient, as presaccular cells migrate to the peritoneum. Although we did not see collagen attachments of parasites to the peritoneum, dissection of myxoworms from bryozoans confirms the presence of firm and physically tough attachments to host tissue at particular stages (B. Okamura, pers. obs.). Our results are in accord that all early stages have sporoplasmosomes that are aligned as seen by Morris and Adams (2006) in T. bryosalmonae. Morris and Adams (2007b) concluded that parasite migration to beneath the host peritoneum was associated with pathology. We did not observe necrotic changes in the host cells. Furthermore our observations revealed that cells in the inner mass of the developing sac were intact, loosely assembled and not syncytial.

Figs. 22-25. Buddenbrockia plumatellae in Plumatella fungosa in early sporogony. Figs. 22, 23. Transverse sections showing clumps of sporogonic cells (almost exclusively B cells) (B) and small non-nucleated cytoplasmic spheres (arrowheads) in the central cavity. The primary Type A cells (A) remain in position and are connected to the muscle bundles (MC) by thin cytoplasmic borders (arrows) and thus maintain a cellular barrier between the cavity and the mural cells. Fig. 24. Transverse section showing a mass of B cells, enlarged from Fig. 23, lying adjacent to muscle (MC) internal to mural cells (M). Many B cells harbour large vacuoles $(\mathrm{EX})$, some as large as nuclei $(\mathrm{N})$, presumed to contain excretory products. Arrow points to the thin cytoplasmic connection between the primary (Type A) sporogonic cell (A) and muscle bundle. Fig. 25. Synaptonemal complexes in nucleus of B cell, indicating meiosis during sporogony. Scale bars: Fig. $22=7.5 \mu \mathrm{m}$; Fig. $23=10.5 \mu \mathrm{m}$; Fig. $24=4.0 \mu \mathrm{m}$; Fig. $25=750$ nm. 
Canning et al.: Early development of Buddenbrockia

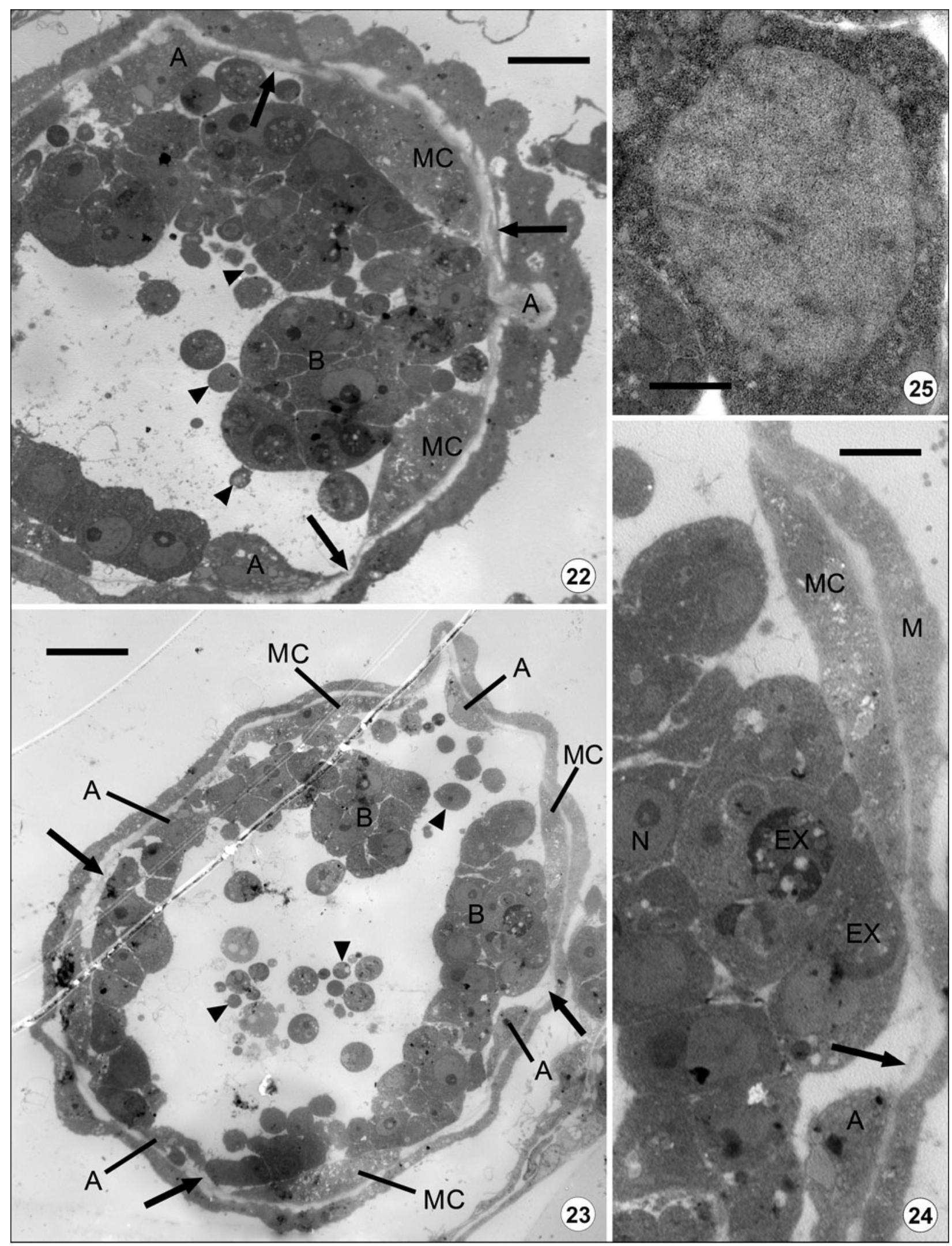


Thus, the terms "pseudosyncytium" and "pseudocapsule" are inappropriate. How the early sac formations penetrate the peritoneum to become free in the coelom remains unknown.

According to McGurk et al. (2006b) the early sacs of B. plumatellae contained acuminate (stellate) cells which were not present in later sacs. However, the stellate cells that they illustrate lie in large sacs bounded by numerous mural cells and are, thus, unlikely to represent very early stages of tissue differentiation. Morris and Adams (2007b) proposed that replication of ectodermal (= mural) and "mesendodermal" (= inner) cells occurred at the base of the myxoworm after the pseudosyncytium had transformed into discrete cells. They further proposed that the "mesendodermal" cells changed to an acuminate (stellate) form at the apex of the myxoworm (presumably the free end) followed by cavity formation and differentiation to mesoderm (muscle) and endoderm. Thus, they proposed that elongation of the myxoworm was effected by replication of cells from the anchored end and that differentiation of tissue occurred simultaneously at the free end. In this respect their results differ from ours. Although we were unable to see the base or the apex of the myxoworms, longitudinal sections of $B$. plumatellae showed that elongation was already advanced at a time when the inner cells were still undifferentiated in the form of a central core of cells with only a narrow gap between the core and mural cells. Thus, at least in myxoworms infecting $H$. punctata, elongation appears to be independent of myogenesis. Myogenesis occurs along the length of the myxoworm from cells arising in the central core. Following the core stage, our study is in agreement that the inner cells differentiate into mesoderm (muscle) and into sporogonic cells representative of endoderm (see discussion below), accompanied by cavity expansion.

Stellate cells are of particular interest as they have been observed several times prior to the studies of McGurk et al. (2006) and Morris and Adams (2007b) cited above. Schröder (1912) extended his light microscopic studies of $B$. plumatellae in $P$. fungosa and described very accurately the arrangement of the four primary cells between the muscle bundles and the secondary cells curving round the inner side of the muscles. He reported on cells of a different type filling the cavity at one end. His speculations on the roles of the different cell types were clearly based on his postulate of female (oogonia) and male (spermatocyte) gamete production. His illustrations suggest that the oogonia correspond to free sporogonic cells (B cells) and the spermatocytes, limited to one end of the myxoworm, to stellate cells. More recently stellate cells packing the central cavity of elongated myxoworms were seen in B. plumatellae in $H$. punctata (Canning et al. 2002) and in quite large sacs of B. allmani in L. crystallinus (Canning et al. 2007). Although the stellate cells clearly occur in the life cycle of malacosporeans, their role is unknown and requires further investigation.

At the earliest stage of myogenesis that we observed, there were already four groups of muscle primordia positioned between the four primary sporogonic (Type A) cells. There remains a gap in our knowledge of the preceding stages. Certain cells, from the apparently undifferentiated cells comprising the core of the myxoworm, must separate to take up their positions close to the basal lamina inside the mural cells, and replicate to form the longitudinal muscles. Transverse sections of these muscle primordia showed clearly that the muscle fibres were deposited initially only in the cell extensions, that projected towards the outside of the muscle block. Longitudinal sections showed that the fibrous parts of the muscle cells all pointed in one direction. This provides a marker for polarity suggesting an anterior/posterior axis, although in which direction the muscles point was not determined. We did not find that muscle fibres crossed from one cell to another, as had been reported by Morris and Adams (2007b).The deposition of muscle fibres on the inner border of the cell was seen only once in the young myxoworms but has been clearly demonstrated in mature myxoworms in $P$. fungosa and $H$. punctata (Canning et al. 2002, Okamura at al. 2002). In our previous studies of B. plumatellae (Canning et al. 2002, Okamura et al. 2002) mature myxoworms were studied in three bryozoan hosts: spores were formed in $P$. fungosa and Fredericella sp. but not in $H$. punctata. Indeed spores have never been observed in repeated collections of this host. In $H$. punctata, it was found that Type B cells remained small and dense while secondary Type A cells (identified initially by their lucent vacuoles) became greatly enlarged packed with large vacuoles and were ultimately degenerate. It was presumed at that time that their function was secretory. In the present study of early stages in $P$. fungosa, the number of secondary Type A cells progressively diminished as the number of $B$ cells increased and were ultimately replaced as the infection approached spore production. The possibility should now be considered that secondary Type A cells are precursors of Type B cells and that in $H$. punctata, a host unable to support spore production, sporogony is halted by the death of the secondary Type A cells. The occurrence of stages of meiosis in B cells in P. fungosa is a strong indication that they are committed to spore formation.

In our present material, as in the earlier study (Canning et al. 2002), junctions between all sporogonic cells were complexes of tight and gap junctions, with the tight part on the inside, ensuring that the entire inner surface acted as a barrier to egression of fluids from the central cavity. The striated tubes that had been so prominent in connecting the primary Type A cells to the mural cells in maturing myxoworms in $H$. punctata were not seen in the early stages in the present study of 
the parasite in the same host. Their role may be nutritional to provide for multiplication of sporogonic cells. In the images of myxoworms with mature muscle in $P$. fungosa, the basal lamina had become a densely fibrous layer to which the muscles were attached. This arrangement must have an important role in the sinuous movements of the "worm" by binding the contractile cells to the wall.

\section{Homologies with cnidarian features}

The great similarity between polar capsules and nematocysts pointed out by Weill (1938) has repeatedly been cited as evidence that myxozoans are cnidarians (see Siddall et al. 1995 and Canning and Okamura 2004 for review). Molecular data now provide strong and independent affirmation of the cnidarian affinity of Buddenbrockia and hence all Myxozoa (Jiménez-Guri et al. 2007a). Here we discuss how other developmental features of B. plumatellae may be homologous.

The most striking feature of $B$. plumatellae is the set of four longitudinal muscle blocks attached to the basal lamina, a feature originally cited as evidence of bilateral affinity (Schröder 1912, Okamura et al. 2002). Muscle homologies may now be drawn with the Scyphozoa, whose polyp stages display similar tetraradial arrangement of independent muscle blocks embedded in the mesogloea (Lesh-Laurie and Suchy 1991).

The polarity of the myxozoan cell junctions may be used to distinguish the different body layers, with the tight regions being present on the outer side of the mural cells and on the inner side of the inner cells. The ectoderm may thus become recognisable when cell junctions form between the outer cells of the early cell complex and the endoderm (gastrodermis) may become identifiable subsequently when the secondary sporogonic cells form a border internal to the muscle blocks Figs. 11, 12).

The establishment of tissue layers in B. plumatellae is dictated by its bizarre early development, which involves no coherent cleavage stages. Instead, isolated cells arise by division later to form a complex of initially unconnected cells. The tissue layers are then defined by the formation of cell junctions and relative position within the cell complex. Thus, the outer epithelial layer is established when cell junctions arise to link the outer cells around a solid core of internalised cells, the latter being fated to become the inner epithelial layer. This process results in a stage structurally reminiscent of the solid gastrula (or stereogastrula) which occurs in the development of many cnidarians (Hyman 1940). The basal lamina appears to be homologous to the mesogloea of cnidarians. Such a developmental pattern, characterised initially by loose collections of dividing amoeboid cells, is somewhat similar to the early stages of Polypodium hydriforme involving division of amoeboid blastomeres as described by Raikova (1994). As far as we are aware such early development does not conform to any other known pattern of development in the Metazoa.

Sexual reproduction in myxozoans is highly modified and has only been recorded in the actinosporean phase of myxosporean life cycles, where synaptonemal complexes, gametogenesis and fertilisation have been described several times (e.g. Marquès 1982, 1983, El Matbouli and Hoffman 1998). In malacosporeans, synaptonemal complexes have been seen in sporogonic cells in T. bryosalmonae (Canning et al. 2000), B. allmani (Canning et al. 2007) and B. plumatellae in Cristatella mucedo Cuvier (Tops et al. 2005) and $P$. fungosa (present data), indicating that restoration of diploidy must occur at some stage in the bryozoan or other, unknown, host. In the Medusozoa sexual reproduction occurs in the medusoid stage of the life history. Although the complete life cycle of $B$. plumatellae is unresolved, it would appear that the medusoid stage has been lost or highly modified. The former would seem more likely since reduction and loss of medusoid stages has occurred repeatedly, particularly in the Hydrozoa (Ruppert et al. 2004), with the retained form (corresponding to the myxoworm of the malacosporeans) becoming the sexual stage via progenesis.

\section{Taxonomy}

In its original description, Tetracapsula bryozoides Canning, Okamura et Curry, 1996 was placed in a new family Saccosporidae within the myxozoan order Multivalvulida Schulman, 1959 and class Myxosporea Bütschli, 1881. At that time the Myxosporea was the only class in the phylum Myxozoa. The species was subsequently transferred to a new class Malacosporea and new order Malacovalvulida by Canning et al. (2000). According to the International Code of Zoological Nomenclature (1999), it is mandated in Article 29 that a family name "must be a noun in the nominative plural" and "formed from the stem of an available generic name". As there is no generic name for a myxozoan from which Saccosporidae could have been derived, the family name is invalid. We propose Buddenbrockiidae, based on the generic name Buddenbrockia, as a suitable replacement name for Saccosporidae because: (a) although its phylogenetic status was not clear at the time, the genus Buddenbrockia is the first described malacosporean parasite of bryozoans (see Schröder 1910); (b) Buddenbrockia plumatellae has now been recognized as a malacosporean myxozoan (Okamura et al. 2002); and (c) the species Tetracapsula bryozoides is currently placed in synonymy with Buddenbrockia plumatellae (see below) and clearly groups with other Buddenbrockia species (Tops et al. 2005, Jiménez-Guri et al. 2007b).

As a result of phylogenetic analyses of $18 \mathrm{~S}$ rDNA sequences (Monteiro et al. 2002), T. bryozoides was proposed as a synonym of $B$. plumatellae (Canning et al. 2002) and a facultative life cycle entailing sac-like or 
vermiform stages was suggested (Monteiro et al. 2002). Later, however, Tops et al. (2005) found a low level of 18S rDNA sequence divergence among vermiform $B$. plumatellae from $H$. punctata, $P$. fungosa and $P$. repens on the one hand and sac-like $B$. plumatellae from C. mucedo on the other. Recent analysis of the rpl23a gene, which encodes a protein found in the large subunit of eukaryotic ribosomes, has revealed a trichotomy for B. plumatellae myxoworms, B. plumatellae $(=T$. bryozoides) sacs, and T. bryosalmonae sacs (Jiménez-Guri et al. 2007b). Although the analysis was unable to resolve the relationships amongst these three malacosporean isolates, there was no support for a conspecific status for vermiform and sac-like $B$. plumatellae. Indeed, the divergence of protein sequences is suggestive of separate species. Further work should help to clarify the situation, with the incorporation of other malacosporean taxa in phylogenetic analyses and more extensive sampling of populations. Since the recognition of the Malacosporea in 2000 (Canning et al. 2000), evidence for four species (including " $T$. bryozoides") has been gathered (Tops et al. 2005) and the spatial scale of sampling populations has expanded greatly (e.g. Okamura et al. 2001, Henderson and Okamura 2004, Hill and Okamura 2007). We can expect that future studies will improve our understanding of malacosporean diversity and taxonomy.

Acknowledgements. We thank Professor T. Wood for enthusiastic hospitality in support of fieldwork, Tanya Knowles for help with figure preparation and Dr. K.E. Kinman for advising us on the ICZN ruling for family names of zoological species. The work received partial funding through grants from the Biotechnology and Biological Sciences Research Council (43/G19271) and the Natural Environment Research Council (NER/A/S/1999/00075).

\section{REFERENCES}

ANDERSON C.L., CANNING E.U., OKAMURA B. 1999: Molecular data implicate bryozoans as hosts for PKX (Phylum Myxozoa) and identify a clade of bryozoan parasites within the Myxozoa. Parasitology 119: 555-561.

CANNING E.U., CURRY A., FEIST S.W., LONGSHAW M., OKAMURA B. 1999: Tetracapsula bryosalmonae n. sp. for PKX organism, the cause of PKD in salmonid fish. Bull. Eur. Assoc. Fish Pathol. 19: 203-206.

CANNING E.U., CURry A., FEIST S.W., LONGSHAW M., OKAMURA B. 2000: A new class and order of myxozoans to accommodate parasites of bryozoans with ultrastructural observations on Tetracapsula bryosalmonae (PKX organism). J. Eukaryot. Microbiol. 47: 456-468.

CANNING E.U., CURRY A., HILl S.L.L., OKAMURA B. 2007: Ultrastructure of Buddenbrockia allmani n. sp. (Myxozoa, Malacosporea), a parasite of Lophopus crystallinus (Bryozoa, Phylactolaemata). J. Eukaryot. Microbiol. 54: 247-262.

CANNING E.U., OKAMURA B. 2004: Biodiversity and evolution of the Myxozoa. Adv. Parasitol. 56: 43-131.

CANNING E.U., OKAMURA B., CURRY A. 1996: Development of a myxozoan parasite Tetracapsula bryozoides gen. n. et sp. n. parasitic in the freshwater bryozoan Cristatella mucedo (Bryozoa, Phylactolaemata). Folia Parasitol. 43: 249-261.

CANNING E.U., TOPS S., CURRY A., WOOD T.S., OKAMURA B. 2002: Ecology, development and pathogenicity of Buddenbrockia plumatellae Schröder, 1910 (Myxozoa, Malacosporea) (syn. Tetracapsula bryozoides) and establishment of Tetracapsuloides n. gen. for Tetracapsula bryosalmonae. J. Eukaryot. Microbiol. 49: 280-295.

El MAtBouli M., HofFMANN R.W. 1998: Light and electron microscopic studies on the chronological development of Myxobolus cerebralis to the actinospore stage in Tubifex tubifex. Int. J. Parasitol. 28: 195-217.

HENDERSON M.W., OKAMURA B. 2004: The phylogeography of salmonid proliferative kidney disease in Europe and North America. Proc. R. Soc., Ser. B, 1549: 1729-1736.

HILL S.L.L., OKAMURA B. 2007: Endoparasitism in colonial hosts: patterns and processes. Parasitology 134: 841-852.

HYMAN L.H. 1940: The Invertebrates, Vol. 1, Protozoa through Ctenophora. McGraw-Hill Book Company, Inc., New York, pp. 259-262.
JiMÉNEZ-GURI E., OKAMURA B., HOLLAND P.W.H. 2007b: Origin and evolution of a myxozoan worm. Integr. Comp. Biol. 47: 752-758.

JiMÉNEZ-GURI E., PHILIPPE H., OKAMURA B., HOLlAND P.W.H. 2007a: Buddenbrockia is a cnidarian worm. Science 317: 116-118.

LESH-LAURIE G.E., SuCHY P.E. 1991: Cnidaria: Scyphozoa and Cubozoa. In: F.W. Harrison and J.A. Westfall (Eds.), Microscopic Anatomy of Invertebrates, Vol. 2. Placozoa, Porifera, Cnidaria, and Ctenophora. Wiley-Liss, New York, pp. 185-266.

MARQUÈS A. 1982: Observation, en microscopie électronique, de complexes synaptonémaux et de premiers stades du cycle d'une Actinomyxidie. C. R. Acad. Sci. Paris 295: 501-504.

MARQUÈS A. 1983: La fécondation et les premiers stades de la sporogénèse d'une Actinomyxidie. C. R. Acad. Sci. Paris; 296: 718-720.

MARQUÈS A. 1986-1987: La sexualité chez les Actinomyxidies: Étude chez Neoactinomyxon eiseniellae (Ormières et Frézil, 1969), Actinosporea, Noble, 1980; Myxozoa, Grassé, 1970. Ann. Sci. Nat. Zool. Paris 8: 81-101.

MCGURK C., MORRIS D.J., ADAMS A. 2006a: Sequential development of Buddenbrockia plumatellae (Myxozoa: Malacosporea) within Plumatella repens (Bryozoa: Phylactolaemata). Dis. Aquat. Org. 73: 159-169.

MCGURK C., MORRIS D.J., AUCHINOCHIE N.A., ADAMS A 2006b: Development of Tetracapsuloides bryosalmonae (Myxozoa: Malacosporea) in bryozoan hosts (as examined by light microscopy) and quantitation of infective dose to rainbow trout (Oncorhynchus mykiss). Vet. Parasitol. 135: 249257.

MonTEIRO A.S., OKAMURA B., HOLLAND P.W.H. 2002: Orphan worm finds a home. Mol. Evol. Biol. 19: 968-971.

MORRIS D.J., ADAMS A. 2006: Proliferative presaccular stages of Tetracapsuloides bryosalmonae (Myxozoa: Malacosporea) within the invertebrate host Fredericella sultana (Bryozoa: Phylactolaemata) Parasitol. Res. 95: 984-989.

MORRIS D.J., ADAMS A. 2007a: Sacculogenesis and sporogony of Tetracapsuloides bryosalmonae (Myxozoa: Malacosporea) within the bryozoan host Fredericella sultana (Bryozoa: Phylactolaemata) Parasitol. Res. 100: 983-992. 
MORRIS D.J., ADAMS A. 2007b: Sacculogenesis of Buddenbrockia plumatellae (Myxozoa) within the invertebrate host Plumatella repens (Bryozoa) with comments on the evolutionary relationships of the Myxozoa. Int. J. Parasitol. 37: 1163-1171.

OKAMURA B., ANDERson C.L., LONGShaw M., FeIST S.W., CANNING E.U. 2001: Patterns of occurrence and 18S rDNA sequence variation of PKX (Tetracapsula bryosalmonae), the causative agent of salmonid proliferative kidney disease. J. Parasitol. 87: 379-385.

OKAMURA B., CURRY A., WOOD T.S., CANNING E.U. 2002: Ultrastructure of Buddenbrockia identifies it as a myxozoan and verifies the bilaterian origin of the Myxozoa. Parasitology 124: 215-223.

RAIKOVA E.V. 1994: Life cycle, cytology and morphology of Polypodium hydriforme, a coelenterate parasite of the eggs of acipenseriform fishes. J. Parasitol. 80: 1-22.

RUPPERT E.E., FOX R.S., BARNES R.D. 2004: Invertebrate Zoology. A Functional Evolutionary Approach. Seventh edition. Thomson Brooks/Cole. Belmont, CA, USA, 157 pp.
SCHRÖDER O. 1910: Buddenbrockia plumatellae, eine neue Mesozoenart aus Plumatella repens L. und Pl. fungosa Pall. Z. Wiss. Zool. 96: 525-537.

SCHRÖDER O. 1912: Weitere Mitteilungen zur Kenntnis der Buddenbrockia plumatellae Ol. Schröder. Verh. Naturhist.-Med. Ver. Heidelberg 11: 230-237.

SidDall M.E., Martin D.S., Bridge D., DesSer S.S., CONE D.K. 1995: The demise of a phylum of protists: phylogeny of Myxozoa and other parasitic Cnidaria. J. Parasitol. 81: 961967.

TOPS S., CURRY A., OKAMURA B. 2005: Diversity and systematics of malacosporean Myxozoa. Invertebr. Biol. 124: 285295.

WEILL R. 1938: L'interpretation des Cnidosporidies et la valeur taxonomique de leur cnidome. Leur cycle comparé à la phase larvaire des Narcomeduses cuninides. Trav. Stn. Zool. Wimereux 13: 724-744.

Accepted 1 August 2008 